\title{
Storytelling in early childhood education: Time to go digital
}

\author{
Maila D. H. Rahiem* (1)
}

\section{*Correspondence:}

mailadinia@uinjkt.ac.id

Department of Early

Childhood Education, UIN

Syarif Hidayatullah, Jakarta,

Indonesia

\begin{abstract}
Digital storytelling blends the ancient art of storytelling with a range of contemporary tools to weave stories together with the author's narrative voice, including digital images, graphics, music and sound. Digital storytelling, as both a teaching method and a learning resource, has been applied in many innovative ways at all levels of education. Digital storytelling supports student learning and allows teachers to adopt innovative and improved teaching methods. Storytelling is a proven and popular pedagogy, while digital storytelling is relatively recent and still seldom used in the setting of early childhood education. Using a case study of a storytelling-art-science club in Jakarta, Indonesia, the researcher explored how and why digital storytelling is used in early childhood education. This club is one of the few organizations that use digital storytelling for teaching and learning programs in early childhood. Data were collected qualitatively using in-depth interviews with four teachers, document analysis, and twice-observations of storytelling activities in each session with 35 and 37 children. The collected data were analyzed using analytical memoing methods. The results indicate that teachers in this club used digital storytelling for several important reasons. They claimed that simple digital technology made storytelling more entertaining, captivating, engaging, communicative and theatrical. This study suggests that the ability of teachers to use digital technology should be enhanced; schools' information and communication technology (ICT) devices should be equipped; some funding should also be allocated by the government to modernize school equipment; while the curriculum should be tailored to meet technological developments, and provide opportunities for children to learn how to make good use of technology.
\end{abstract}

Keywords: Digital storytelling, Early childhood education, ICT, Educational technology

\section{Introduction}

Storytelling is an important teaching resource with a strong presence in all societies since the evolution of human language and has a highly effective role in the education of young children (Phillips, 2000). Young children enjoy reading, writing and listening to stories, and from the stories, they are able to understand more about society and life in general. Telling and dramatizing stories is a fairly widespread addition to the pre-school curriculum, primarily because of the exposure this practice has gained through Vivian Paley's writings that addressed the effects of storytelling on social and cognitive development of children (Wright et al., 2008).

(c) The Author(s) 2021. This article is licensed under a Creative Commons Attribution 4.0 International License, which permits use, sharing adaptation, distribution and reproduction in any medium or format, as long as you give appropriate credit to the original author(s) and the source, provide a link to the Creative Commons licence, and indicate if changes were made. The images or other third party material in this article are included in the article's Creative Commons licence, unless indicated otherwise in a credit line to the material. If material is not included in the article's Creative Commons licence and your intended use is not permitted by statutory regulation or exceeds the permitted use, you will need to obtain permission directly from the copyright holder. To view a copy of this licence, visit http://creativeco mmons.org/licenses/by/4.0/. 
Both storytelling and story reading have been found to be successful educational strategies that create significant improvements in language acquisition in young children (Lucarevschi, 2016; Miller \& Pennycuff, 2008; Speaker et al., 2004); improve their oral or spoken language (Cooper, 2009; Cremin et al., 2018; Isbell et al., 2004; Typadi \& Hayon, 2010); develop reading comprehension (Craig et al., 2001; Haven \& Ducey, 2007); make sense of basic mathematics (Casey et al., 2008; Goral \& Gnadinger, 2006; Pramling \& Samuelsson, 2008); explain science (Hu et al., 2020; Preradovic et al., 2016; Valkanova \& Watts, 2007; Walan, 2019); prepare for school (Nicolopoulou et al., 2015); communicate effectively (Sundin et al., 2018); help children to learn and appreciate their world (Cremin et al., 2018; Vélez \& Prieto, 2018); improve cross-cultural communication (AlJafar \& Buzzelli, 2004); and promote moral and social development (Bailey et al., 2006; Burns \& Rathbone, 2010; Thambu, 2017).

Storytelling has grown and developed over time, adopting a dynamic, contemporary presence through settings and functions. Emergent digital technologies transform the complexity of storytelling and open up new avenues for collaborative approaches (O'Byrne et al., 2018). Digital storytelling is a creative process that mixes conventional storytelling with digital technology, including a computer, video camera, and sound recorder (Ohler, 2013). It is a modern pedagogical initiative that has arisen from the proliferation of digital technology (Wang \& Zhan, 2010).

Through the simplification, interaction and affordability of technology, digital storytelling methods have been quickly and widely spreading. It has become a reliable learning platform, as new technologies have become cheaper and more commonly accessible to a more considerable number of people (McLellan, 2006). Digital storytelling is used at all levels of education from early childhood to higher education. Several studies have also generated qualitative evidence that technology has beneficial effects on encoding, visual perception, creative thinking, and fine motor skills (Zomer \& Kay, 2014). Many teachers develop storytelling practices using digital technology, while more and more schools are now using digital storytelling that combines the art of storytelling with a variety of digital multimedia, such as images, audio, and video (Robin, 2008).

Technology allows teachers to access innovative and improved instructional approaches to support children's learning and growth (Wang \& Hoot, 2006). Additionally, technology also helps children from low- to medium-income households excel in vocabulary, literacy and math testing, and their overall readiness for school (Wright et al., 2001). Technology opens up greater opportunities for children to learn, as education practitioners increasingly incorporate technology and digital media into their classrooms, so children have the same right to participate and learn (Cross et al., 2009).

Digital storytelling supports students' learning by encouraging them to organize and express their ideas and knowledge in a distinctive and meaningful way (Robin, 2008). Digital stories allow educators to gain insights into children's learning (Kervin \& Mantei, 2016). It has also proven to be a powerful resource for inspiring teachers to engage in conversation with their young audiences and to teach and promote the comprehension of the story's facts and messages (Kosara \& Mackinlay, 2013). As teachers and students discuss stories, it may encourage students to turn their experiences, perceptions, and imagination into narratives. Digital stories are versatile ways to have a voice (Nilsson, 2010). Educators use digital storytelling as a motivational tool to draw students' 
attention and increase their interest in seeking new ideas (O'Byrne et al., 2018). It is a deeply reflective learning resource and the self-representation of its creators (KullaAbbott \& Polman, 2008; Nelson \& Hull, 2008). It allows the creators not only to express themselves but also to convey their view of the world (O'Byrne et al., 2018); and to reflect and evaluate their thought in a cyclical cycle and inevitably record progress (Danielson, 2008).

Nowadays, in young children's lives, screen media is becoming more and more popular. Research indicates that preschoolers are often familiar with digital technology before being introduced to books (Brody, 2015; Hopkins et al., 2013). Digital storytelling has strengthened the conceptual understanding of the course material by the preschoolers more than conventional storytelling (Kocaman-Karoglu, 2015). Digital stories even allow children younger than six to understand a new language (Verdugo \& Belmonte, 2007). Young children are able to enjoy a story through digital media, without understanding how to read it (Judge et al., 2004). They could enhance communication skills by learning how to organize their thoughts, ask a question, express opinions, and construct narratives while interacting with others and computers in the creation of digital stories (O’Byrne et al., 2018).

Although considering the many advantages of using digital storytelling in teaching and learning, and the evidence indicating that this instructional approach appears to be suitable for young learners, it is still not very prevalent in early childhood education (Blackwell et al., 2014). Many parents and educators are indeed opposed to the use of technology for young children. A number of technology devices, such as TVs, smartphones and tablets, are warned to have a negative impact on children (Blackwell et al., 2014). Parents and educators worry about the morally detrimental effects of ICT, its lack of sensitivity to its cultural and language needs and its primacy at the expense of other social needs (Albirini, 2006).

Some work has linked to watching television for long periods during childhood to concentration issues in adolescence (Landhuis et al., 2007; Zimmerman \& Christakis, 2005). Many groups concerned with children's health, including governments and medical societies, advocate for partially or fully limiting screen time for children and adolescents (Gottschalk, 2016). For example, the American Association of Pediatrics (Ponti et al., 2017), Canadian Paediatric Society (Hill et al., 2016), Australian Government Department of Health (2014), and New Zealand Ministry of Health (2017) have limits of one hour per day of high-quality programming for children up to the age of five. Moreover, the German Federal Ministry of Health (Pfeifer \& Rütten, 2017) limit the screen times for this age group at $30 \mathrm{~min} /$ day.

Other challenges and difficulties in the implementation of ICT in the education sector are exacerbated by, among other things, the unequal infrastructure that enables the use of technology across schools and the unpreparedness of Human Resources in facilitating the implementation of ICT in schools. For several developing countries and underdeveloped countries, the difference in the provision of information and communication technology resources is very evident (Khan et al., 2012) In Indonesia, for example, the Minister of Communication and Information Technology reported that more than 80,000 of the 280,000 schools, including elementary school (SD), junior high school (SMP) and high school (SMA), are not connected to the Internet (Ministry 
Communication \& Information Technology, 2018). In the statement, the Minister indicated that connecting primary-secondary education would be the priority and would therefore not involve early childhood schooling. Early childhood education in Indonesia is not mandatory.

Human resource issues in the use of technology include a lack of educators' experience and abilities in the use of educational technology. Results from international research show that many students and teachers have little to no digital skills to make effective use of these technologies, which restrict their potential effect, can have adverse implications for student learning, and may increase educational inequality, especially in developing countries (Hinostroza, 2018).

Media and technology are tools that only function when they are used properly. Technology effects can rely on factors such as the type of technology used and its function (Bavelier et al., 2010). Both media and technology have the ability to benefit teachers and learners when they are used appropriately, yet it can also be easily misused, leading to negative effects, so it is imperative that it is used wisely.

In this study, the researcher investigated a case study of a storytelling-art-science club in Jakarta, Indonesia, that uses digital technology in its educational program. The club runs weekly art, science, and social and moral values programs, through contextualized storytelling activities that are supported digitally. This club is one of the few early childhood education organizations that use ICT tools in their activities. The club has become a role model of creating compelling and entertaining digital storytelling activities for children for schools and teachers in Jakarta and beyond. This club has developed an innovative and creative digitally supported contextualized storytelling teaching approach that has inspired other schools and teachers to use. By researching the club in greater detail, the researcher learned how and why the club uses ICT tools in its program, what are the advantages of using this approach and how the approach they use can be adapted and even improved to help support other early childhood education institutions.

This research is significant because education in early childhood is an important first stage of a child's education and is also an essential foundation for future child development. There is also a lack of knowledge because existing research on the use of ICT primarily focuses on primary to higher education levels. This work provides a useful insight into the technological advancements in early childhood education and provides an overview of what activities have been conducted effectively at a children's club in Jakarta, Indonesia.

\section{Material and methods}

The research was conducted using a qualitative approach in the form of a single case study. Data were collected from various sources, such as semi-structured interviews, observations, and analysis of documents for the triangulation process. Semi-structured interviews were conducted to obtain in-depth information by asking open-ended questions. The researcher prepared a set of core questions and several additional questions related to the central issues. During the actual interviews, the researcher further improved the original questions. The researcher observed the digital storytelling activities performed by the teachers on two different occasions. The researcher observed 
what digital media teachers used during storytelling, how they used the media, how children responded to stories, and how digital technology was used. Observations utilize the researcher's senses by looking and listening systematically and meaningfully as they become involved in data collection (McKechnie, 2008). The researcher also analyzed some documents, including weekly, monthly, and annual storytelling programs and storytelling scripts. These data sources provided additional information on how the teachers use digital technology in their art-science-storytelling programs and also provided confirmatory evidence of the information obtained from both the interviews and observations.

The researcher protected the participants and their data throughout the data collection and analysis to ensure the study's reliability and validity. The researcher transcribed all of the material and was, therefore, able to interact with the data and create meaning by listening to the recordings. A member's check was also carried out to ensure that the researcher correctly understood what the participants had said. The participants were also informed of their right to withdraw from the research at any point, while permission to conduct the research was also granted by all the schools and parents involved.

The researcher took several important steps to maintain the validity of this research. Qualitative analysis validity refers to the trustworthiness of the data interpretation (Eisenhart \& Howe, 1992; Lincoln \& Guba, 1985). First, triangulation involves using various data sources and methods to validate an interpretation or inference that is justified (Bogdan \& Biklen, 2003; Korstjens \& Moser, 2018). Methodological triangulation was used by collecting data through various data collection methods, which included indepth interviews, observations, and document analysis. Data triangulation refers to the use of multiple data sources where the participant differs in terms of gender, age, educational background and length of teaching experience. Second, member checks (Merriam, 2009) were carried out in which all the participants reviewed the transcription of an interview to confirm the researcher's understanding. The verbatim files were then also sent to the participants after transcribing the interviews. They verified that the information they provided during the interview was correct and, if not, was then removed or changed. Third, the methods, procedures, and data used were "appropriate" (Leung, 2015). The researcher ensured that the research question was valid for the desired outcome, the methodology selection was appropriate to address the research question, the design was valid for the methodology, the sampling and data analysis was appropriate, and finally, the findings and conclusions were true for the sample and context.

\section{Participants}

Purposive sampling was used in this research. The single case being investigated is a storytelling-art-science club that has performed a digital storytelling program called the magic show. Four teachers participated in the research. This research merely explored the views and experiences of the teachers in leading the magic show program. The teachers become the focal source of data for the investigation, while their interaction with the students during the storytelling events became additional data. The researcher observed the program twice, the first observation had 35 children, while the second had 37 children. 
The magic show integrates storytelling with digital technology, science, the arts, and moral education. The club was established in 2000 and now has a program in ten kindergartens and seven elementary schools throughout Jakarta. Each school allocates time for the magic show once or twice a week. Furthermore, the club also actively conducts a storytelling workshop for teachers and parents in Jakarta and across Indonesia. Teachers at the club are also trainers in creative storytelling for teachers and parents. The researcher has chosen this club as a case study because it has a long history of using digital storytelling with digitally supported and stories contextualization for early childhood education, and the club is becoming a creative teaching model and reference for kindergarten teachers.

The teachers involved in this research are GMA, STA, LRS, and DWI. The names of the teachers have been disguised using abbreviated names to respect the integrity of the participants and increase their confidence to talk deeply about their experiences, knowledge, beliefs, and understanding of the use of digital storytelling activities. The actual name of the club was also intentionally obscured to ensure further anonymity.

All teachers have taught in pre-school for between 10 and 35 years. They all have extensive experience using digital storytelling as teaching tools and have a favorable view of the use of storytelling for early childhood education. STA is one of the club's founders. He has been running the club since it was established. STA has 18 years of teaching experience and a bachelor's degree in science education. DWI has 35 years of teaching experience. She is the developer of the program at the club. She has a bachelor's degree in kindergarten teaching. GMA has 18 years of teaching experience. He has been a club teacher for 10 years. He is a well-known storyteller and storyteller trainer. He has a diploma in kindergarten teaching. LRS has 10 years of teaching experience. She has been a teacher at the club for the last 3 years. She holds a diploma in kindergarten teaching and a bachelor's degree in English education.

\section{Data analysis}

Analytical memos, as introduced by Saldaña (2016), have been used for data analysis. Analytical memos provide a means for the researcher to record their thoughts during the research process and code memos as additional data for the study. Saldaña (2016) suggests two main stages of coding: the first-cycle codes are those initially assigned to the data, then the second-cycle codes, in which those initial codes are grouped into meaningful categories, themes, or constructs (Miles et al., 2014). The cycle is not a single linear event; the qualitative analytical process is cyclical (Saldaña, 2016).

Following Saldaña's approach (2016), the researcher coded each interview transcript individually in the first cycle and then re-coded it. After coding the second interview, the researcher compared the first interview to the second one. The researcher continued this process with each interview transcript and document analysis, developing themes through this ongoing analysis of the data. In the second cycle, the researcher reorganized and reanalyzed the data coded in the first coding cycle. The primary objective of second-cycle coding is to develop a sense of categorical, thematic, conceptual, and theoretical organization from the first-cycle code array (Saldaña, 2016). The researcher changed codes, added new codes, and dropped a few codes to pursue study themes. Finally, the researcher made 
assertions and the declarative statements of summative synthesis. The assertions are based on the researcher's fieldwork observations, supported by evidence from the data corpus.

A description of the steps in conducting this research is as follows (Fig. 1).

\section{Results}

How and why is digital storytelling used in early childhood education? The findings show that teachers use simple digital technology, and that the use of technology has made storytelling more entertaining, exciting, communicative, and theatrical.

The researcher analyzed the data in two cycles. In the first cycle, there were 16 codes and 9 sub-codes that explained the data. The following diagram shows the codes and sub-codes of the data (Fig. 2).

The researcher continued the second-cycle coding. She grouped the codes and sub-codes into categories. After that, she looked for any themes that emerged from the categories (Fig. 3).

Four themes have been created: (1) entertaining and captivating; (2) engagement and communication; (3) theatrical; (4) simple digital technology. The first three answered the question of why teachers use digital storytelling in moral education. The last theme, simple digital technology, explained how teachers use digital technology. Based on a careful examination of the corpus, the researcher developed an assertion from the themes. The summative claim based on the evidence is that using simple digital technology, the teachers make storytelling entertaining, exciting, communicative, and theatrical.

\section{Entertaining and captivating}

The teachers explained how digital technology, makes storytelling more enjoyable, entertaining and captivating. With the used of special effects, it keeps children listening to the stories attentively. Children love to see their teachers dress up and have props.

GMA said that he loved to surprise children and make them smile. Using digital technology made the story more fun, exciting, and engaging.

"I'm mixing storytelling and magic in a show to entertain my young audience... I love to surprise them and make them smile. Usually, umm, they said that without magic shows, the stories weren't fun and exciting, they were waiting and ecstatic to see my magic show. We also have a monthly storytelling activity at this school, umm... my show! I combined the storytelling with the magic. There are also exciting characters who wear attractive costumes, storytelling should be engaging, if necessary, with props, and umm... the children will be happy, happy. Other teachers see my storytelling show; they imitate me, and they create new ways of their own." (GMA)

STA figured out that the "magic" works when she saw the kids staring so intently throughout the show, sometimes their eyes did not even blink.

"Look at them, they stare to us, to the show, sometimes not even blink. The magic works. Storytelling using the sound system and PPT is captivating." (STA) 


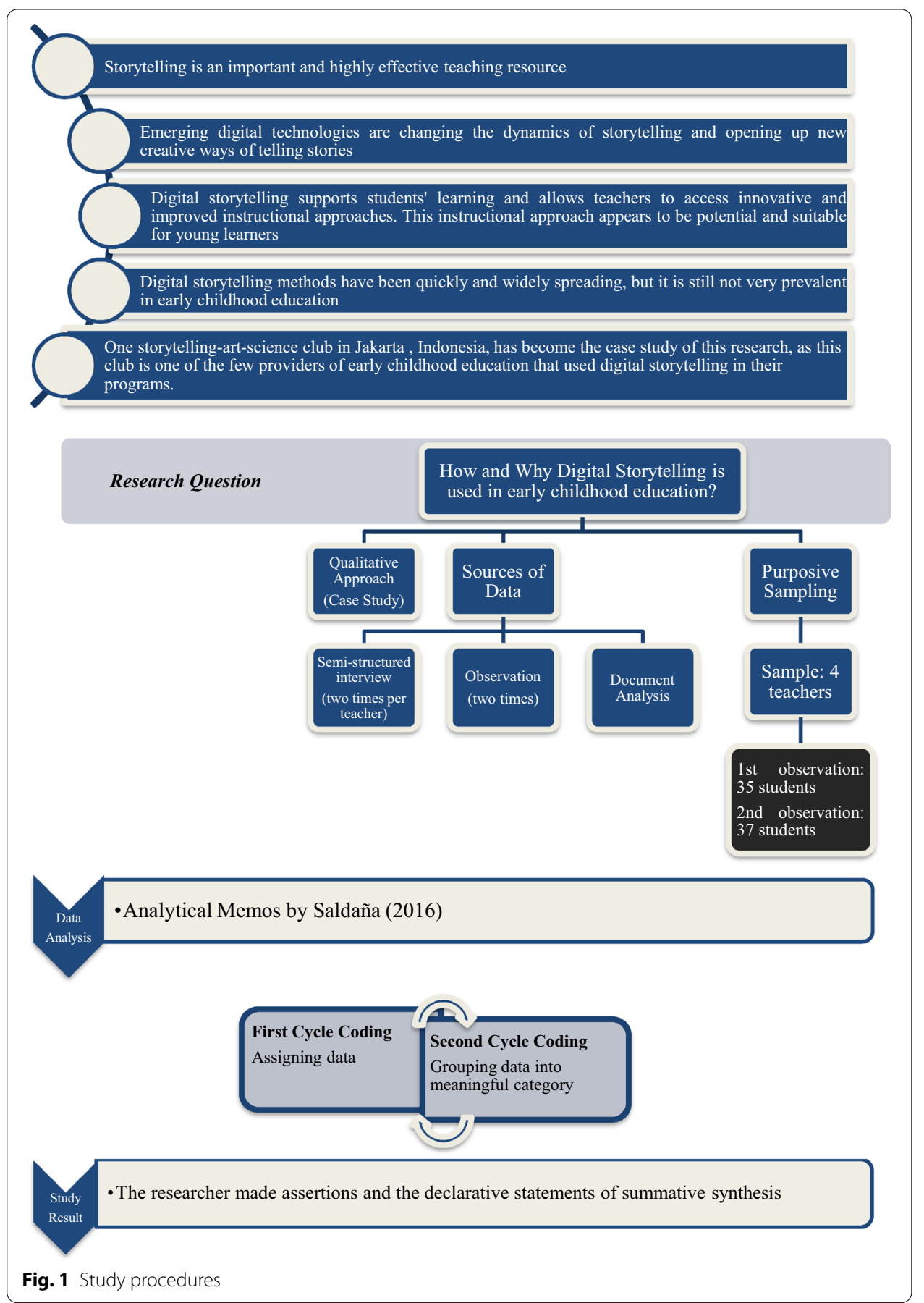

\section{Engagement and communication}

The teachers explained that even simple media used in the show could engage children to communicate with them. The teachers and children can discuss the stories, allowing the teachers the opportunity to ask questions about the story. 


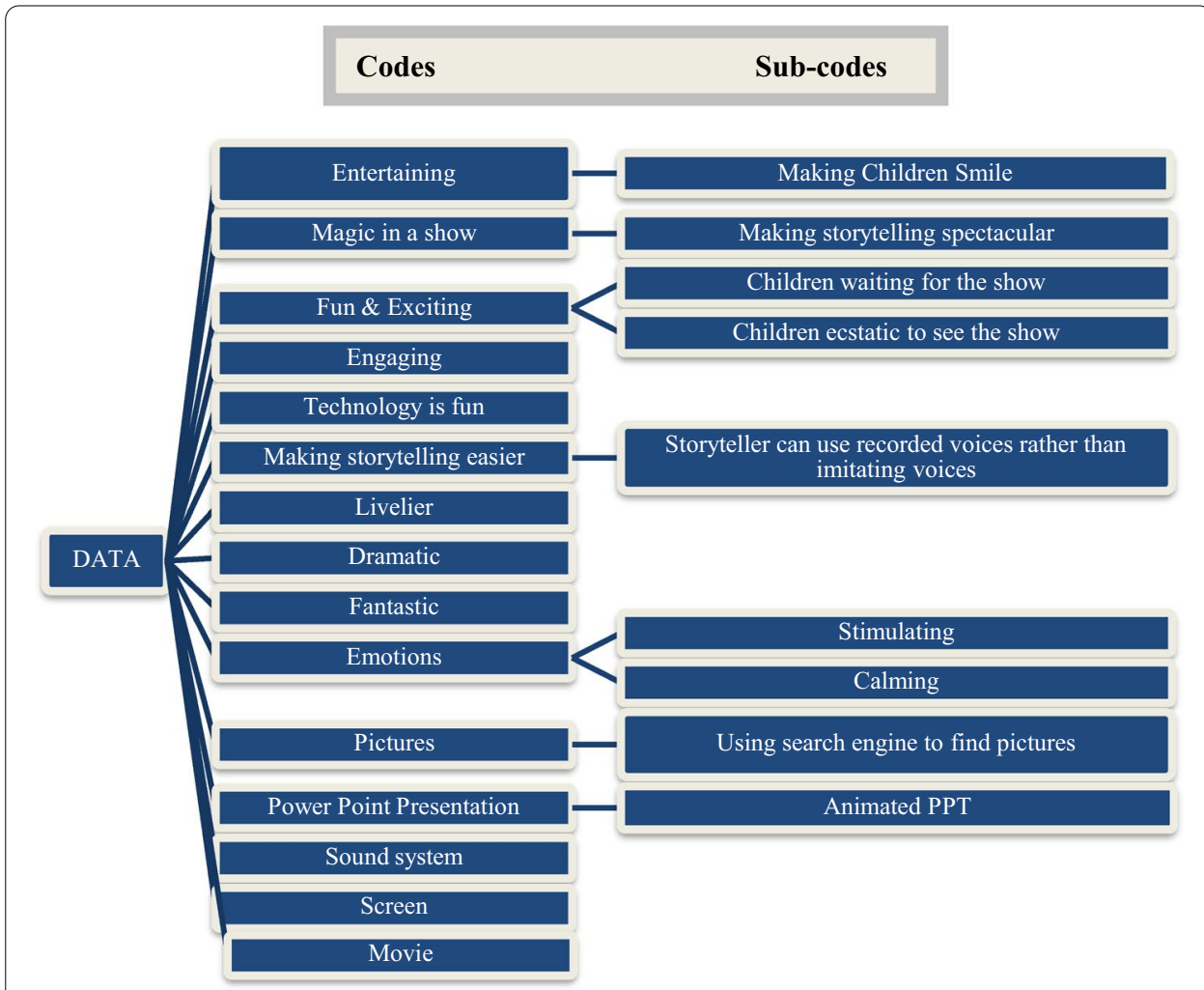

Fig. 2 First cycle coding

DWI explained that she needed the pictures to help ensure that the children listened attentively and made it easier for them to understand what she was talking about.

"It made the children listen (pausing) attentively. I brought a couple of photos. They saw a greenhouse, hmm, and other kinds of houses, wooden houses, brick houses, and others." (DWI)

LRS asked questions about the story's characters and what the next scene of the show will be. She found this communication much easier when she had something actually to show the children, which they were engaged in.

"I asked them some questions. I showed them some images of the story's characters. And I asked the children who they were. When I have photos or videos, it's easier to talk to them. I show them, and with the colors and drawings or pictures, they get excited. I also asked them what had to be the next scene." (LRS)

In addition to the interviews, the researcher also conducted two observations. The researcher found that continuous communication occurred during the presentation. The teacher was engaging children in the story by asking them questions and telling them to do some body-movements or facial expressions or mimic them. The children even became involved in the story by playing the story characters.

The first observation was with GMA, who holds a degree in chemistry from a renowned university in Jakarta, Indonesia, and who led the magic show. The show was 


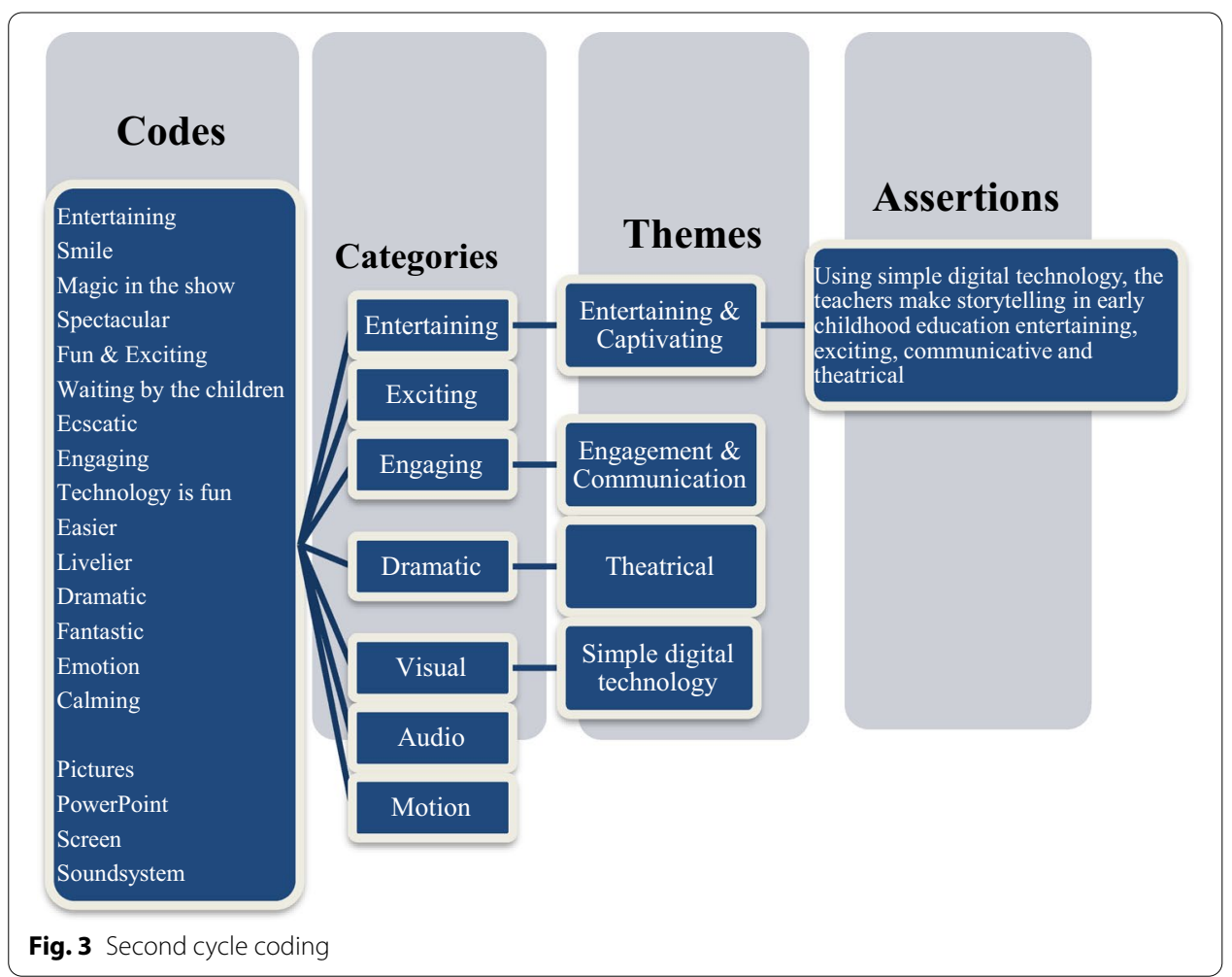

presented in an Islamic kindergarten in the south of Jakarta. The story presented was the miracle of the prophet Abraham. The storytelling began with the question, "Who knows the prophet, Abraham?" The children replied. Most of them knew the prophet. A fire animation was then played in the PowerPoint presentation. Then the teacher asked, "What is the miracle of the prophet Abraham?" The children explained that he could not be burned in the fire. "They were trying to burn him in the fire! It was a miracle that he was safe. How could it have happened?".

The teacher continued, "Today, I am going to have a challenge for you." The children listened attentively to him. There was a big question mark on the screen, and background sounds like a comedy show when something surprising happens. "We're going to play with fire and balloons," he said dramatically to the children, "Fire is hazardous... it could burn anything... anything!" There was a massive fire in the woods on the screen. "We're going to start with a small fire." There was a lit candle on the screen in the darkroom. "What's going to happen if we put the paper on the candle?" There was a piece of paper and a candle shown on the screen. The children responded that it would burn. On the screen, the paper was burned by the flame from the candle.

The teacher asked, "What about balloons?" A picture of colorful balloons was animated on the screen. The teacher walked into the center of the classroom, and he said, "The challenge is how to make the balloon not burst when we put it on top of the lit candle!" The children exclaimed enthusiastically. The teacher got a balloon out of his toy box. "Let's fill the balloon with water." He filled the balloon with water. "If the balloon is filled with water, is it burned by fire?" He lit a candle but warned the children not to try 
the experiment without adult supervision. The screen had changed. There was a blue background, and written in bold large capital letters was the word-EXPERIMENT. "Ready, huh?" asked the teacher.

"Yes, yes!" the children answered.

"That's not loud enough, are you ready?" The children answered louder and said they were ready for the experiment. The teacher showed how the water-filled balloon did not burn or burst. He placed the balloon at the top of the lit candle that he had prepared in the classroom. This is what happened to the prophet Abraham. He wasn't burned in the fire. The screen was transformed into an animated fire.

He went on to explain, "Water is a great substance to soak up heat. The thin balloon allows the heat to pass through and warm the water very quickly. As the water, nearest to the flame heats up, it begins to rise and is replaced by colder water at the bottom of the balloon. The colder water then soaks up more heat, and the process repeats itself. In fact, the exchange of water happens so often that it keeps the balloon from popping! Actually, the spot on the bottom of the balloon is carbon. The carbon was deposited on the balloon by the flame, and the balloon remains undamaged."

That long explanation kept the children silent, although they did not seem to understand what he was talking about fully. "Abraham was not burned; that was his miracle. This balloon couldn't be burned; this is science." The teacher continued the discussion with the children. In this storytelling activity, the teacher used graphics to dramatize, attract the children's attention, and explain stories better. The teacher also added some recorded voices to the background.

During the second observation, STA led the storytelling show in a non-faith-based kindergarten in South Jakarta, Indonesia. STA told the researcher he loved to use characters from popular cartoon movies so that children are familiar with the character. He used the character from the Frozen movie that day. "There's a little girl. Her name is Elsa." On the screen was Elsa, a beautiful girl with platinum blonde hair, blue eyes, and a blue princess-like dress. The teacher had already recorded the scene. He made a balloon character that was shaped into a depiction of Elsa. STA continued, "This morning, Elsa is too lazy to go to school. She is so sleepy. Her mother is trying to wake her up."

The screen showed a silent movie scene where Elsa was sleeping in her bed, and her mother, also made of a balloon, was trying to wake her up. The teacher imitated Anna, Elsa's mother's voice, "Wake up, Elsa." Elsa was still asleep. The teacher asked the children, "How do you wake Elsa up?" One child said that she would sprinkle water on her face. Another said she would shake her body. Another one said she would scream in her ears. A little boy said, "Prick it, Elsa is a balloon." The teacher asked, "A balloon is going to burst if we prick it?" All the children answered, "Yes!!!" The teacher said, "Hmm, not always." The screen was dark blue, with bold lettering underneath, I'M NOT GOING TO BURST and a balloon under the letters.

The teacher took an inflated balloon and a needle. "I'm going to poke the balloon with the needle." Some of the children covered their ears, and some shouted, "No!" The teacher said, "I'm going to show you how the balloon won't blow up," The children looked confused. "I'm going to show you how." The background sound turned into a drumming 
sound. "1, 2, 3," he poked the balloon, and it did not burst. The children were astonished. "How could it have happened?" One boy said, "Magic!" The teacher explained, "The rubber in the balloon consists of many long molecules that are linked together. It is similar to the way all the noodles on a plate of spaghetti stick together." The screen shows a picture of spaghetti on a plate. "These long molecules are called polymers." The children were more excited about the spaghetti picture on the screen. Some children were even mimicking eating the spaghetti.

"The rubber at the end of the balloon is thicker than the middle part of the balloon, which means it is less stretchable. There is less force pulling on it, therefore. If we poke this area, the balloon won't pop. But if you prick the middle part, it's going to pop."

The teacher then allowed some kids to try pricking the balloon. "So Elsa is still asleep. Her mother was trying to wake her up again. Who likes Elsa, who finds it hard to wake up in the morning?" STA used a PowerPoint presentation to portray the scenes from his story, which displayed the relevant images and also created sound. His explanation of the balloon seemed too advanced for the children. However, he successfully retained the attention of the children to listen to his story throughout.

\section{Theatrical}

The teachers also shared their perspectives on using simple technology to make storytelling activities more realistic and spectacular.

"Technology makes the story more lively, exciting, dramatic, and fantastic!" (STA)

GMA added that he brought magic to his storytelling. Using magic tricks, a combination of arts and science and presented using digital technology.

"I use magic tricks to tell or read stories, so kids can understand the story, I need tricks. The magic tricks make the stories livelier, the tricks play with the children's emotions, and help them relax if the stories are too tense." (GMA)

STA added that when conducting storytelling activities in a large group, it needs a sound system and a screen to display animated PowerPoint slides. The end result needs to be a show-something truly amazing.

"I don't need it in small groups. I can simply read a book as it is. But in a large group, I need a sound system, Ummm... and a screen. I agree that we must be interested in reading the story, umm... preparing, and preparing the storytelling as a show. For me, telling or reading a story is not a regular activity, it's a spectacular show." (STA)

\section{Simple digital technology}

The researcher listed some of the digital technologies used by the teachers during the twoobserved shows, which includes: images, PowerPoint presentation, sound system, microphone, screen, LCD projector, and laptop. All of these tools are simple digital technology, 
which the teachers used to contextualize the stories. The researcher also questioned the teachers during the interviews about how the show was planned and performed and the technologies used for the show. Below are a few excerpts from the interviews:

LRS used a PowerPoint presentation, showing some of the pictures she had found on the internet. She presented the PowerPoint program as moving animated slides to maintain the audience's interest.

"Usually, I use PowerPoint presentations, umm... I get the animations from the Internet, then display them on PowerPoint so that children are becoming more interested in listening to the story." (LRS)

GMA also used movies he had created in PowerPoint for storytelling activities. He said they were easy-to-make movies.

"We made the movies, easy ones, moving slides, hmm in PowerPoint." (GMA)

For preparing the show, teachers often use search engines like Google to find pictures related to the discussion.

"We're using a variety of media, we're using technology, now we can get images quickly from google. Yesterday, we talked about different types of homes, and we got some pictures on the internet." (DWI)

Teachers acknowledged that digital storytelling required additional planning beforehand in comparison to regular storytelling. However, it is this additional planning that is vital to the success of the storytelling presentation. DWI agreed on the importance of having a screen and a sound system. She needed to prepare every detail of her storytelling presentation to give her confidence.

"I always want to prepare meticulously; it's a show. I have to imagine every detail one night before when I read the story. I'm supposed to be well prepared, the prop, the screen, and the sound system. Without being well prepared for the show, I don't trust myself." (DWI)

There is more preparation required for presentations on digital storytelling, but all of that makes it easier for teachers to present stories at the end. STA said that technology is fun. He thought it was easier to tell stories using digital technology rather than the oldfashioned way. Instead of making different voices, he could use a digital sound recording to create voices or even search for different sounds online.

"Technology is fun. It makes storytelling a lot easier. You don't need to be a great storyteller that makes a variety of voices. Use Technology, use balloons, or more advanced Technology, umm... use props, it's different from the old days, umm... there's no need to make a lot of voices, make the elephant sound, turn on the microphone and play the recording sound, the elephant sound. (STA) 


\section{Discussion}

Young people today are becoming more technologically knowledgeable and increasingly engaged in activities using a computer screen; even very young children respond and are motivated by creating computer-based materials, such as digital stories (Robin, 2016). Van Gills (2005) summed up the advantages of using digital storytelling in education into five categories. Two of them are the same as this study's conclusions, namely: digital storytelling makes the explanation or practice of certain subjects more compelling and improves the involvement of children in the learning process. The teachers in this study also explained that studying the arts, science and moral education using digital storytelling was more interesting and captivating. They also provided examples of how the use of digital storytelling actively involves children in the learning process. Gills' three conclusions, which are not the same as the findings of this study, are that digital storytelling offering more variation in current practice than traditional methods customize the student learning process, and creates real-life situations more easily and affordably (Van Gils, 2005). Another explanation the teachers stated in this research which Van Gills was not addressing is that digital technology makes stories more dramatic or theatrical.

Digital storytelling is entertaining and captivating; it motivates children to take part in learning. Smeda et al. (2014) found that student engagement, achievement, and motivation are enhanced by integrating fun and exciting technologies. Choi (2018) confirmed that the teaching strategies used in entertainment had become vital components for growing student interaction and learning outcomes. Digital storytelling is a ground-breaking pedagogical strategy that can involve children in profound and meaningful learning, and it is a reliable tool for combining educational messages with learning experiences to create more engaging and exciting learning environments (Smeda et al., 2014). Digital storytelling is a practical approach to developing a positive learning environment. The strategy has the potential to improve student participation and provide better educational outcomes for learners.

Digital storytelling is engaging and communicative; O'Byrne et al. (2018) examined how children's computer interaction (CCI) intersects the process of story development in the early childhood classroom setting. They concluded that children gain improved communication skills by learning how to coordinate their thoughts, ask questions, express opinions, and create narratives when engaging with others and with the computers in the development of digital stories. They claimed that children, as young as pre-school age, are capable of developing their digital stories using a computer program with the help of their teachers. This was not the practice of teachers in this magic show storytelling program. The children were not involved in the making of digital storytelling. The teachers prepared the stories beforehand, and they were also the ones who presented the digital stories.

O'Byrne et al. (2018) studied the engagement of children in digital storytelling programs in kindergartens in the US, while this research was performed in Indonesia, which may be one of the factors behind why the children were not involved in the creation of their own digital stories. Most kindergartens in Indonesia are private, faithbased, and operated by communal or religious organizations (Rahiem et al., 2020; Rahim \& Rahiem, 2013). The four schools visited by the researcher are considered 
to be well established and better-equipped schools. However, not all classrooms are provided with a pc or laptop, and they did not have a computer lab that the children could all use, which is likely one of the major factors behind why the children in the observations did not create their own digital stories.

This study reveals that digital technology makes storytelling for arts, science and moral education program, more engaging, even when children do not make the stories, and it encourages them to share their thoughts, ideas and experiences. Children got engaged in conversations before, during and after storytelling. Digital storytelling is grounded on a student-centered learning approach (Bromberg et al., 2013). Therefore, it promotes and actively supports student involvement in their learning process, which has been shown to produce effective learning outcomes (Dupain \& Maguire, 2007). Research has shown that active learning is an effective way to learn subject-matter (Roussou, 2004). The researcher saw how digital storytelling successfully engaged the children to the characters in the stories, the storytellers, and the other people listening. The teachers have more chances to connect with children because they have things to chat about, such as clips and music that complement the stories. Children answered the teacher's questions and participated in the storytelling activity. As the characters jumped up, they jumped. They interacted with the characters and were intrigued by the colors, motions and sounds from the show. Digital storytelling fosters imagination and creates opportunities for children to express their thoughts and feelings.

Digital storytelling is theatrical; in this study, the teachers exemplify how they transformed storytelling activities into a dramatic and entertaining magic show. Dramatizing stories is particularly valuable for children. The play-like action of dramatizing stories is highly motivating for young children and allows them to think in more sophisticated ways (Wright et al., 2008). The teachers demonstrated that storytelling has become simpler with modern technology. They do not have to know how to make animals and other sounds, as they can simply play recorded sounds instead. The recorded sounds of the animals make the stories more realistic and also dramatic. Compared to the conventional storytelling, digital storytelling is an even more powerful means of communication as visual aids, still-images, music, and the emotionally expressive voices of the speaker strengthen the narrative. Moreover, different educational applications of digital storytelling are in compliance with how people learn, which has made digital storytelling an especially important role in many aspects of education (Wang \& Zhan, 2010).

To prepare children for a changing world, it is crucial to use technology in early childhood education (Lindahl \& Folkesson, 2012). The teachers in this study were using simple and easy to prepare digital technologies. They used pictures they had searched for using Google and then printed them, or they showed the pictures as slides while telling stories to children. Most of the time, they used PowerPoint to display videos or slides. They added music, lighting, and combined it with real-life reading and discussions. They use simple digital technology to contextualize stories. Speakers, LCD Projectors, and microphones were often used during storytelling activities. They did not use sophisticated computer systems and equipment, and rather they used only the PowerPoint application.

Teachers can feel overwhelmed by the option and variety of educational technologies available in the fast-moving world (Murcia et al., 2018). Teachers should concentrate not 
on technology but the result of their activities. Teachers in this study cautiously planned the storytelling activities to ensure they met the curriculum. They chose a computer PowerPoint program that they were familiar with and had been using since their college years.

From the two observations made by the researcher and compared to the PowerPoint Core Skills Checklist for Basic, Intermediate, and Advanced Levels from Northern College (2020)), the researcher observed that the teachers' capacity to make presentations was at an advanced level. The teachers did not just put text and images in the presentation they made, they incorporated audio and video recordings (from computer files, YouTube, and other sites) and sound effects into animations, added action buttons, associated a sound to a slide transition, modified slide transition effects, and timing, and created a self-running presentation. Their presentations were very artistic and entertaining.

Out of all the teachers in this club, many teachers still prefer to tell stories more traditionally and conventionally, no matter how simple digital technology might accentuate the effects. It is time to go digital. Using simple digital technology, the teachers in this research are convinced that digital technology makes storytelling more entertaining, captivating, engaging, communicative, and theatrical. However, not all early childhood educators can utilize and optimize the use of a computer program for educational purposes. PowerPoint is one of the programs that many are familiar with it. PowerPoint programs can be developed into a learning media that attracts early childhood interest because this program has many features that, when used correctly, will produce digital storytelling work that is entertaining, engaging, and a good source of learning for early childhood education. The program is also convenient for beginners and can be learned independently.

Therefore, the teachers' digital technology skills should be improved to maximize the benefits of using it for education purposes. Teachers need to be technologically literate and have the understanding, expertise, and experience of child development philosophy and the implementation of effective practices to conduct successful digital storytelling activities. Teachers require training to integrate technology into the classroom (Judge et al., 2004). They need training, professional development opportunities, and examples of successful practice to develop the technology and media knowledge and skills needed for a successful digital storytelling program. Digital storytelling is an incredibly good technology resource for capturing, designing, analyzing and combining visual images with written text. Incorporating visual images with written text increases students' understanding and the speed that they can comprehend (Burmark, 2004). Teachers who can create their own digital stories may find that they can be extremely useful not only in engaging students in the content but also in promoting the discussion of the topics addressed in a story and making complex or abstract material more comprehensible. The training should help the teachers feel more confident about using digital tools in their classrooms.

Given what is known about how and why digital storytelling can be used in the classroom to engage and motivate both students and teachers, other factors should also be considered: equipping more schools with ICT devices; allocating some government funds to modernize school equipment; designing a curriculum to integrate 
technological advances and providing opportunities for children to learn using technology. Those last three suggestions in this report have not been much discussed. It is an idea for further study to consider how to tackle these barriers.

\section{Conclusion}

While this study has provided important theoretical and empirical information, it is not without its limitations. The most evident limitation is that this study has explored one single case only. Thus, the experiences told and practice observed are only specific to teachers in the storytelling-art-science club. More exploration of the practice and perception of classroom teachers with more significant samples is needed to gain information on how the frames are shaped in a more common situation. One important topic for future research would be the relationship and dynamics between pedagogical frames and practical frames in early childhood education using storytelling and technology integration.

A second limitation is that this study only examines the kinds of perceptions and practices of the teachers in using digital technology in storytelling for early childhood arts science program. While such information is valuable, further studies are required to determine how the children perceive and experience it themselves. The researcher in this study conducted two observations and saw how the children reacted and interacted during digital storytelling activities. However, the researcher did not take the opportunity to talk with the children. It will be challenging to interview children, but it is not impossible to do this with the prior informed consent from the parents/ guardians, ethical guidance, and research protocol. A future study could look at the children's insights and experiences or combine both the teachers' and children's perceptions or even add the parents' experiences and insights on the use of digital storytelling in early childhood education.

\section{Acknowledgements}

The author acknowledges the teachers participated in this research and Faculty of Education UIN Syarif Hidayatullah Jakarta for their kind support. She also wishes to deeply thank Adam Batten for his review and informative feedback throughout the production of this writing.

\section{Authors' contributions}

MDHR conceived and designed the research protocols, performed the data collections, analyzed the data, prepared figures and/or tables, authored or reviewed drafts of the paper. The author read and approved the final manuscript.

Funding

The author received no funding for this work.

Availability of data

The datasets generated during and/or analyzed during the current study are available from the corresponding author on reasonable request.

Declaration

Competing interests

The author declares that she has no competing interests.

Received: 15 April 2020 Accepted: 13 March 2021

Published online: 06 April 2021 


\section{References}

Albirini, A. (2006). Cultural perceptions: The missing element in the implementation of ICT in developing countries. International Journal of Education and Development Using Information and Communication Technology, 2(1), 49-65.

Al-Jafar, A., \& Buzzelli, C. A. (2004). The art of storytelling for cross cultural understanding. International Journal of Early Childhood, 36(1), 35-48. https://doi.org/10.1007/BF03165939

Australian Government Department of Health. (2014). Australia's Physical Activity and Sedentary Behaviour Guidelines For Adults (18-64 years). Australian Government, 1-8. https://www1.health.gov.au/internet/main/publishing.nsf/ content/F01F92328EDADA5BCA257BF0001E720D/\$File/brochurePA Guidelines_A5_18-64yrs.pdf

Bailey, B. P., Tettegah, S. Y., \& Bradley, T. J. (2006). Clover: Connecting technology and character education using personally-constructed animated vignettes. Interacting with Computers, 18(4), 793-819. https://doi.org/10.1016/j. intcom.2005.11.013

Bavelier, D., Green, C. S., \& Dye, M. W. G. (2010). Children, wired: For better and for worse. Neuron, 67(5), 692-701. https:// doi.org/10.1016/j.neuron.2010.08.035

Blackwell, C. K., Lauricella, A. R., \& Wartella, E. (2014). Factors influencing digital technology use in early childhood education. Computers and Education, 77, 82-90. https://doi.org/10.1016/j.compedu.2014.04.013

Bogdan, R., \& Biklen, S. K. (2003). Bogdan, R. C \& Biklen, S. K. (2003). Qualitative Research for Education: An introduction to Theories and Methods (4th ed.). New York: Pearson Education group. (pp. 110-120). Qualitative Research for Education: An Introduction to Theories and Methods.

Brody, J. E. (2015, July 6). Screen Addiction Is Taking a Toll on Children. The New York Times. https://well.blogs.nytimes. com/2015/07/06/screen-addiction-is-taking-a-toll-on-children/

Bromberg, N. R., Techatassanasoontorn, A. A., \& Diaz Andrade, A. (2013). Engaging students: Digital storytelling in information systems learning. Pacific Asia Journal of the Association for Information Systems, 1, 22. https://doi.org/10.17705/ 1 pais.05101

Burmark, L. (2004). Visual presentations that prompt, flash \& transform. Media and Methods. https://doi.org/10.1002/casp. 778

Burns, D. P., \& Rathbone, A. (2010). The relationship of narrative, virtue education, and an ethic of care in teaching practice. Education, 1991, 2002.

Casey, B., Erkut, S., Ceder, I., \& Young, J. M. (2008). Use of a storytelling context to improve girls'and boys' geometry skills in kindergarten. Journal of Applied Developmental Psychology, 29(1), 29-48. https://doi.org/10.1016/j.appdev.2007.10. 005

Choi, G. Y. (2018). Learning through digital storytelling: exploring entertainment techniques in lecture video. Educational Media International, 55(1), 49-63. https://doi.org/10.1080/09523987.2018.1439710

Cooper, P. (2009). The classrooms all young children need: Lessons in teaching from Vivian Paley. Chicago: University of Chicago Press.

Craig, S., Hull, K., Haggart, A. G., \& Crowder, E. (2001). Storytelling addressing the literacy needs of diverse learners. Teaching Exceptional Children, 33(5), 46-51. https://doi.org/10.1177/004005990103300507

Cremin, T., Flewitt, R., Swann, J., Faulkner, D., \& Kucirkova, N. (2018). Storytelling and story-acting: Co-construction in action. Journal of Early Childhood Research, 16(1), 3-17. https://doi.org/10.1177/1476718X17750205

Cross, C. T., Woods, T. A., \& Schweingruber, H. (2009). Mathematics learning in early childhood: Paths toward excellence and equity. New York: National Academies Press.

Danielson, L. (2008). Making reflective practice more concrete through reflective decision making. The Educational Forum, 72(2), 129-137. https://doi.org/10.1080/00131720701805009

Dupain, M., \& Maguire, L. L. (2007). Health digital storytelling projects. American Journal of Health Education, 38(1), 41-43. https://doi.org/10.1080/19325037.2007.10598941

Eisenhart, M. A., \& Howe, K. R. (1992). Validity in educational research. In The handbook of qualitative research in education.

Enrique Hinostroza, J. (2018). New challenges for ICT in education policies in developing countries: The need to account for the widespread use of ICT for teaching and learning outside the school. In ICT-supported innovations in small countries and developing regions (pp. 99-119). Springer International Publishing. https://doi.org/10.1007/ 978-3-319-67657-9_5

Goral, M. B., \& Gnadinger, C. M. (2006). Using storytelling to teach mathematics concepts. Australian primary mathematics classroom, 11(1), 5. http://eric.ed.gov/ERICWebPortal/recordDetail?accno=EJ793906

Gottschalk, F. (2016). Impacts of technology use on children: Exploring literature on the brain, cognition and well-being. OECD Education Working Papers, 26(3), 313-316. https://doi.org/10.1089/cap.2015.0029

Haven, K. F., \& Ducey, M. (2007). Crash course in storytelling. In Crash course series.

Hill, D., Ameenuddin, N., Chassiakos, Y. R., Cross, C., Radesky, J., Hutchinson, J., Boyd, R., Mendelson, R., Moreno, M. A., Smith, J., \& Swanson, W. S. (2016). Media and young minds. Pediatrics, 138, 5. https://doi.org/10.1542/peds.2016-2591

Hopkins, L., Brookes, F., \& Green, J. (2013). Books, bytes and brains: The implications of new knowledge for children's early literacy learning. Australian Journal of Early Childhood. https://doi.org/10.1177/183693911303800105

Hu, J., Gordon, C., Yang, N., \& Ren, Y. (2020). "Once Upon A Star": A science education program based on personification storytelling in promoting preschool children's understanding of astronomy concepts. Early Education and Development. https://doi.org/10.1080/10409289.2020.1759011

Isbell, R., Sobol, J., Lindauer, L., \& Lowrance, A. (2004). The effects of storytelling and story reading on the oral language complexity and story comprehension of young children. Early Childhood Education Journal, 32(3), 157-163. https:// doi.org/10.1023/B:ECEJ.0000048967.94189.a3

Judge, S., Puckett, K., \& Cabuk, B. (2004). Digital equity. Journal of Research on Technology in Education, 36(4), 383-396. https://doi.org/10.1080/15391523.2004.10782421 
Kervin, L., \& Mantei, J. (2016). Digital storytelling: Capturing children's participation in preschool activities. Issues in Educational Research, 26(2), 225-240.

Khan, M. S. H., Hasan, M., \& Clement, C. K. (2012). Barriers to the introduction of Ict Into education in developing countries: the Example of Bangladesh. International Journal of Instruction, 5(2), 61-80.

Kocaman-Karoglu, A. (2015). Telling stories digitally: An experiment with preschool children. Educational Media International, 52(4), 340-352. https://doi.org/10.1080/09523987.2015.1100391

Korstjens, I., \& Moser, A. (2018). Series: Practical guidance to qualitative research. Part 4: Trustworthiness and publishing. European Journal of General Practice. https://doi.org/10.1080/13814788.2017.1375092

Kosara, R., \& Mackinlay, J. (2013). Storytelling: The next step for visualization. Computer, 46(5), 44-50. https://doi.org/10. 1109/MC.2013.36

Kulla-Abbott, T., \& Polman, J. L. (2008). Engaging student voice and fulfilling curriculum goals with digital stories. Technology, Humanities, Education, \& Narrative, 25, 77.

Landhuis, C. E., Poulton, R., Welch, D., \& Hancox, R. J. (2007). Does childhood television viewing lead to attention problems in adolescence? Results from a prospective longitudinal study. Pediatrics, 120(3), 532-537. https://doi.org/10.1542/ peds.2007-0978

Leung, L. (2015). Validity, reliability, and generalizability in qualitative research. Journal of Family Medicine and Primary Care, 4(3), 324. https://doi.org/10.4103/2249-4863.161306

Lincoln, Y. S., \& Guba, E. G. (1985). Establishing trustworthiness. Naturalistic Inquiry, 2, 256.

Lindahl, M. G., \& Folkesson, A.-M. (2012). Can we let computers change practice? Educators' interpretations of preschool tradition. Computers in Human Behavior, 28(5), 1728-1737. https://doi.org/10.1016/j.chb.2012.04.012

Lucarevschi, C. R. (2016). The role of storytelling on language learning: A literature review. Working Papers of the Linguistics Circle of the University of Victoria, 26(1), 24. https://search.proquest.com/docview/1886242426?accountid $=15181 \%$ OAhttp://openurl.york.ac.uk/openurl/44YORK/44YORK_services_page?url_ver=Z39.88-2004\&rft_val_fmt=info:ofi/ fmt:kev:mtx:journal\&genre=article\&sid=ProQ:ProQ\%3Allba\&atitle=The+role+of+storytelling +

McKechnie, L. (2008). Unstructured observation. In L. M. Given (Ed.), The SAGE Encyclopedia of Qualitative Research Methods (pp. 908-908). SAGE Publications, Inc. https://doi.org/10.4135/9781412963909.n476

McLellan, H. (2006). Digital storytelling: Bridging old and new. Educational Technology: The Magazine for Managers of Change in Education, 46(5), 26-31.

Merriam, S. B. (2009). Qualitative research: A guide to design and implementation. Jossey-Bass. https://doi.org/10.1097/ NCl.0b013e3181edd9b1

Miles, M. B., Huberman, M., \& Saldana, J. (2014). Drawing and verifying conclusions. Qualitative Data Analysis: A Methods Sourcebook, 11, 16.

Miller, S., \& Pennycuff, L. (2008). Power of story: Using storytelling to improve literacy learning. Journal of Cross-Disciplinary Perspectives in Education, 1(1), 36-43.

Ministry Communication and Information Technology. (2018). 2019 Semua Sekolah Terkoneksi Internet. Ministry of Communication and Information Technology Republic of Indonesia. https://www.kominfo.go.id/content/detail/15627/ 2019-semua-sekolah-terkoneksi-internet/0/sorotan_media

Murcia, K., Campbell, C., \& Aranda, G. (2018). Trends in Early Childhood Education Practice and Professional Learning with Digital Technologies. Pedagogika, 68, 3. https://doi.org/10.14712/23362189.2018.858

Nelson, M. E., \& Hull, G. A. (2008). NelsonHull2008SelfPresentation-ABakhtinianPerspective.pdf. In K. Lundby (Ed.), Digital storytelling, mediatized stories-Self representation in new media (pp. 123-144). New York: Peter Lang Publisher.

New Zealand Ministry of Health. (2017). Sit Less (pp. 1-2). Physical Activity Guidelines for Children and Young People.

Nicolopoulou, A., Cortina, K. S., Ilgaz, H., Cates, C. B., \& de Sá, A. B. (2015). Using a narrative- and play-based activity to promote low-income preschoolers' oral language, emergent literacy, and social competence. Early Childhood Research Quarterly, 31, 147-162. https://doi.org/10.1016/j.ecresq.2015.01.006

Nilsson, M. (2010). Developing voice in digital storytelling through creativity narrative and multimodality. Seminar Net, $6(2), 148-160$

Northern College. (2020). Microsoft PowerPoint 2010 Basic Skills Checklist. http://www.northernc.on.ca/leid/wp-content/ uploads/2018/04/NC-PowerPoint-skills-checklist-final.pdf

O'Byrne, W. I., Houser, K., Stone, R., \& White, M. (2018). Digital storytelling in early childhood: Student illustrations shaping social interactions. Frontiers in Psychology. https://doi.org/10.3389/fpsyg.2018.01800

Ohler, J. B. (2013). Digital Storytelling in the Classroom: New Media Pathways to Literacy, Learning, and Creativity (2nd ed.). London: Sage.

Pfeifer, K., \& Rütten, A. (2017). National Recommendations for Physical Activity and Physical Activity Promotion. In Gesundheitswesen, Supplement (Vol. 79). https://doi.org/10.1055/s-0042-123346

Phillips, L. (2000). Storytelling: The seeds of children's creativity. Australasian Journal of Early Childhood, 25(3), 1-5. https:// doi.org/10.1177/183693910002500302

Ponti, M., Bélanger, S., Grimes, R., Heard, J., Johnson, M., Moreau, E., Norris, M., Shaw, A., Stanwick, R., van Lankveld, J., \&Williams, R. (2017). Screen time and young children: Promoting health and development in a digital world. Paediatrics \& Child Health, 22(8), 461-468. https://doi.org/10.1093/pch/pxx123

Pramling, N., \& Samuelsson, I. P. (2008). Identifying and solving problems: Making sense of basic mathematics through storytelling in the preschool class. International Journal of Early Childhood, 40(1), 65-79. https://doi.org/10.1007/ BF03168364

Preradovic, N. M., Lesin, G., \& Boras, D. (2016). Introduction of digital storytelling in preschool education: A case study from Croatia. Digital Education Review, 30, 94-105. https://doi.org/10.1344/der.2016.30.94-105

Rahiem, M. D. H., Abdullah, N. S. M., \& Krauss, S. E. (2020). Moral education through dramatized storytelling: Insights and observations from Indonesia kindergarten teachers. International Journal of Learning, Teaching and Educational Research, 19(3), 475-490. https://doi.org/10.26803/ij|ter.19.3.26

Rahim, H., \& Rahiem, M. D. H. (2013). The use of stories as moral education for young children. International Journal of Social Science and Humanity, 2(6), 454-458. https://doi.org/10.7763/IJSSH.2012.V2.145 
Robin, B. R. (2008). Digital storytelling: A powerful technology tool for the 21st Century Classroom. Theory Into Practice, 47(3), 220-228. https://doi.org/10.1080/00405840802153916

Robin, B. R. (2016). The power of digital storytelling to support teaching and learning. Digital Education Review, 30, 17-29. https://doi.org/10.1344/der.2016.30.17-29

Roussou, M. (2004). Learning by doing and learning through play. Computers in Entertainment, 2(1), 10. https://doi.org/10. $1145 / 973801.973818$

Saldaña, J. (2016). The Coding Manual for Qualitative Researchers (No. 14). Sage.

Smeda, N., Dakich, E., \& Sharda, N. (2014). The effectiveness of digital storytelling in the classrooms: a comprehensive study. Smart Learning Environments, 1(1), 6. https://doi.org/10.1186/s40561-014-0006-3

Speaker, K. M., Taylor, D., \& Kamen, R. (2004). Storytelling: Enhancing language acquisition in young children. Education, 125(1), 3-14.

Sundin, A., Andersson, K., \& Watt, R. (2018). Rethinking communication: Integrating storytelling for increased stakeholder engagement in environmental evidence synthesis. Environmental Evidence, 7(1), 6. https://doi.org/10.1186/ s13750-018-0116-4

Thambu, N. (2017). Storytelling and story reading: A catalyst for inculcate moral values and ethics among preschoolers. International Journal of Academic Research in Business and Social Sciences, 7, 6. https://doi.org/10.6007/JJARBSS/v7-i6/ 3143

Typadi, E., \& Hayon, K. (2010). Storytelling and story acting: Putting the action into interaction. In F. Griffiths (Ed.), Supporting children's creativity through music, dance, drama and art: Creative conversations in the early years (pp. 69-88). London: Routledge.

Valkanova, Y., \& Watts, M. (2007). Digital story telling in a science classroom: Reflective self-learning (RSL) in action. Early Child Development and Care, 177(6-7), 793-807. https://doi.org/10.1080/03004430701437252

Van Gils, F. (2005). Potential applications of digital storytelling in education. 3rd twente student conference on IT. http:// wwwhome.ctit.utwente.nl/ theune/VS/Frank_van_Gils.pdf

Vélez, I. B., \& Prieto, J. L. (2018). Literature as a therapeutic instrument in the health-disease process in childhood. Enfermeria Global. https://doi.org/10.6018/eglobal.17.2.299201

Verdugo, D. R., \& Belmonte, I. A. (2007). Using digital stories to improve listening comprehension with Spanish young learners of English. Language Learning and Technology, 11(1), 87-101.

Walan, S. (2019). Teaching children science through storytelling combined with hands-on activities - a successful instructional strategy? Education, 47(1), 34-46. https://doi.org/10.1080/03004279.2017.1386228

Wang, S., \& Zhan, H. (2010). Enhancing teaching and learning with digital storytelling. International Journal of Information and Communication Technology Education, 6(2), 76-87. https://doi.org/10.4018/jicte.2010040107

Wang, X. C., \& Hoot, J. L. (2006). Information and communication technology in early childhood education. Early Education \& Development, 17(3), 317-322. https://doi.org/10.1207/s15566935eed1703_1

Wright, C., Bacigalupa, C., Black, T., \& Burton, M. (2008). Windows into children's thinking: A guide to storytelling and dramatization. Early Childhood Education Journal, 35(4), 363-369. https://doi.org/10.1007/s10643-007-0189-0

Wright, J. C., Huston, A. C., Murphy, K. C., \& st. Peters, M., PiAt-on, M., Scantlin, R., \& Kotler, J. . (2001). The relations of early television viewing to school readiness and vocabulary of children from low-income families: The Early Window Project. Child Development, 72(5), 1347-1366. https://doi.org/10.1111/1467-8624.t01-1-00352

Zimmerman, F. J., \& Christakis, D. A. (2005). Children's television viewing and cognitive outcomes. Archives of Pediatrics \& Adolescent Medicine, 159(7), 619. https://doi.org/10.1001/archpedi.159.7.619

Zomer, R. N., \& Kay, R. K. (2014). Technology use in early childhood education: A review of the literature. Journal of Educational Informatics, 1, 1-25.

\section{Publisher's Note}

Springer Nature remains neutral with regard to jurisdictional claims in published maps and institutional affiliations.

\section{Submit your manuscript to a SpringerOpen ${ }^{\circ}$ journal and benefit from:}

- Convenient online submission

- Rigorous peer review

- Open access: articles freely available online

- High visibility within the field

- Retaining the copyright to your article

Submit your next manuscript at $\boldsymbol{\nabla}$ springeropen.com 